\title{
Development of a continuously operated reactor for the limited hydrolysis of whey protein by trypsin
}

\author{
Antoine Margot, ${ }^{\mathrm{a}}$ Erwin Flaschel $^{\mathrm{b} *}$ and Albert Renken ${ }^{\mathrm{c}}$ \\ ${ }^{a}$ Nestlé R\&D Center Konolfingen, Sonnrainstrasse 19, CH-3510 Konolfingen, 1, Switzerland \\ ${ }^{\text {b}}$ Technische Fakultät, Universität Bielefeld, P.O. Box 1001 31, D-33501 Bielefeld, Germany \\ 'Institut de génie chimique, Ecole polytechnique fédérale de Lausanne, CH-1015 Lausanne, Switzerland
}

(Received 21 January 1997; revised version received 5 April 1997; accepted 5 April 1997)

\begin{abstract}
A continuously operated reactor was developed for the limited hydrolysis of whey protein using soluble trypsin. It consisted of a stirred tank followed by a tubular device. A stirred tank was used because it allowes $\mathrm{pH}$ control to be achieved more easily. The tubular reactor was applied in order to achieve a high level of conversion without $\mathrm{pH}$ control. The tubular reactor was equipped with static mixers for approximating plugflow behaviour. The behaviour of the reaction system under floating $\mathrm{pH}$ in both parts of the reactor was evaluated separately prior to verification of the results in a pilot-plant which consisted of the combination reactor. The operating temperature and $\mathrm{pH}$ in the stirred tank were investigated as the main variables of the process. (C) 1998 Elsevier Science Ltd
\end{abstract}

Keywords: trypsin, whey protein, infant food, continuous reactor, CSTR, tubular reactor.

Abbreviations: CSTR, continuous stirred tank reactor, NPN, fraction of non-protein nitrogen or soluble protein, TR, tubular reactor, SN-TCA, fraction of soluble (protein) nitrogen in trichloroacetic acid, WPC. whey-protein concentrate.

\section{Nomenclature}

$c$

Substrate concentration in terms of peptide bonds ( $m o l$ litre $^{-1}$ )

E Enzyme concentration $\left(\mathrm{kg} \mathrm{kg}^{-1}\right)$

$\mathrm{pK}_{\mathrm{a}} \quad$ Acid dissociation exponent

$S \quad$ Substrate concentration $\left(\mathrm{kg} \mathrm{kg}^{-1}\right)$

$\mathrm{t} \quad$ Time, reactor operating time $(\mathrm{min})$

$T_{\mathrm{c}} \quad$ Temperature $\left({ }^{\circ} \mathrm{C}\right)$

$V_{\mathrm{R}} \quad$ Reactor volume $\left(\mathrm{m}^{3}\right)$

$\dot{V} \quad$ Flow rate $\left(\mathrm{m}^{3} \mathrm{~min}^{-1}\right)$

$X \quad$ Degree of hydrolysis, fraction of peptide bonds cleaved, NPN

Molar fraction

$x$

$x_{\mathbf{H}}$

$Y$ fraction of peptide bonds cleaved Yield of soluble protein, NPN according to $\beta$

$\tau$

Indices

a

b

c

$\mathrm{f}$

$\mathrm{N}$

0

\section{Introduction}

Hypoallergenic infant food commonly contains peptides obtained from readily available natural proteins which are treated with proteolytic enzymes to achieve limited protein hydrolysis, thereby destroying the allergenic epitopes of natural proteins [1]. Processes for manufacturing these peptides commonly use discontin-
Buffer capacity
Space time, residence time $\left(=V_{\mathrm{R}} / \dot{V}\right)(\mathrm{min})$

Referring to the acid form

Referring to the base form

Referring to the carboxyl group

Referring to final conditions

Referring to the amino group

Referring to initial conditions

\footnotetext{
*To whom correspondence should be addressed.
} the SN-TCA method 
uously operated stirred tank reactors in the presence of soluble enzymes such as trypsin. Continuous reactor operation is of major interest because the product is in high demand and there is a need to manufacture a product of constant quality. Both criteria favour continuously operated reactors over batch reaction systems. However, the peculiarities of protein hydrolysis limit the choice of reactor design. Thus, immobilization of enzymes on porous supports is inefficient due to the presence of macromolecular substrates which in addition, lead to support fouling [2]. Ultrafiltration membrane reactors have been operated with limited success for the same reasons $[3,4]$. Another major characteristic of protein hydrolysis is that substrate conversion is sometimes accompanied by a drastic drop in $\mathrm{pH}$, which may require $\mathrm{pH}$-controlled reactors to be used [5].

A reactor was designed for continuous operation being based on the use of soluble enzymes, and in which most of the $\mathrm{pH}$ drop is avoided by $\mathrm{pH}$ control. This was achieved with a two stage design, consisting of a continuously operated stirred tank reactor preceeding a tubular reactor. The initial $\mathrm{pH}$ and operating temperatures were investigated so that these main operating variables could be set in order to achieve a fraction of soluble protein of at least $60 \%$.

\section{Materials and methods}

Partialy demineralized whey-protein concentrate (WPC) with an average protein content of $22 \%(\mathrm{w} / \mathrm{w})$ and porcine pancreatic trysin, PTN 6.0 $\mathrm{S}$ (Novo
Nordisk, Denmark) were used. The trypsin preparation contained $10.2 \mu \mathrm{mol} \mathrm{g}^{-1}$ of active enzyme as estimated by active-site titrations according to the method of Chase and Shaw [6]. All experiments were performed at an initial substrate concentration of WPC of $20 \%$ $(\mathrm{w} / \mathrm{w})\left(S_{0}=0 \cdot 2\right)$. The standard condition with respect to $\mathrm{pH}$ was $7 \cdot 3$. The WPC contained an initial fraction of (apparently) soluble protein of $4.8 \%\left(Y_{0}=0.048\right)$ consisting mainly of soluble peptides as well as ammonia. Trypsin was solubilized in $1 \mathrm{~mm} \mathrm{HCl}$ containing $5 \mathrm{mM} \mathrm{CaCl}_{2}$ prior to being added or fed to the reaction systems.

The fraction of protein soluble in $13.6 \%$ trichloroacetic acid (SN-TCA index) expressed as non-protein nitrogen (NPN) or fraction of soluble protein $(Y)$ was calculated from correlations with base consumption in the case of $\mathrm{pH}$-controlled reactor experiments or determined directly. Details about batch-reactor operation, analytical procedures and the correlation of the SN-TCA index (NPN) with base consumption may be found in a previous report [5]. Protein solutions were treated for $5 \mathrm{~min}$ at $90^{\circ} \mathrm{C}$ prior to starting the reaction by the addition of enzyme solution. In the case of pH-controlled reactions, a solution of $4 \mathrm{~m} \mathrm{KOH}$ was fed into the reactor automatically in order to achieve constant $\mathrm{pH}$. All experiments were performed with an enzyme-substrate ratio of $0.01 \mathrm{~kg} \mathrm{~kg}^{-1}$.

For continuous operation a pilot-plant was designed consisting of a tubular reactor (TR) in series with a continuous stirred tank reactor (CSTR) as shown in Fig. 1. The geometry of the CSTR is detailed in the

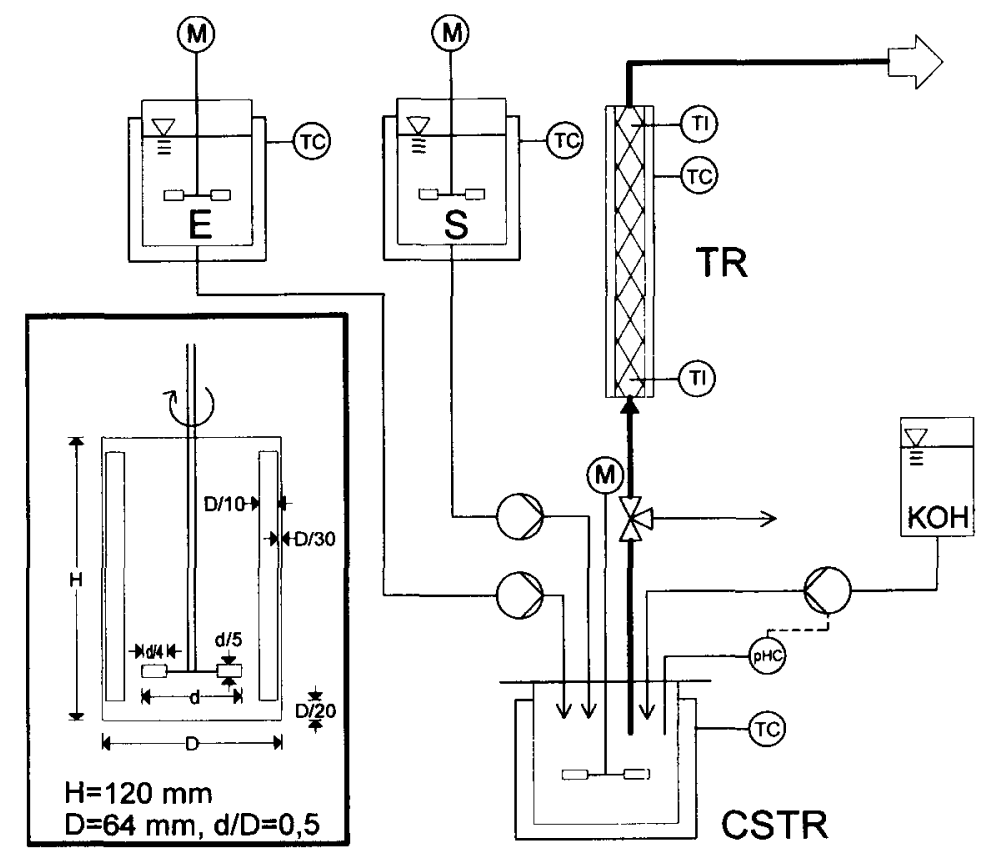

Fig. 1. Flow sheet of the pilot-plant reactor. The insert shows the geometry of the continuous stirred tank reactor (CSTR). The tubular reactor (TR) contains static mixers. Reservoirs for enzyme solution (E), substrate solution (S), and $4 \mathrm{M} \mathrm{KOH} \mathrm{(KOH)} \mathrm{are}$ shown. 
insert of Fig. 1. It consisted of a cylindrical tank equipped with a six-bladed Rushton turbine and four baffles. During operation the CSTR was filled completely. A water jacket served for thermostating. The turbine was kept at a constant speed of $1000 \mathrm{~min}^{-1}$ by means of a speed-controlled electric motor (model MS, Ismatec SA, Switzerland). The CSTR was fed with both a substrate solution, by means of a peristaltic pump (model IP-4, Ismatec SA, Switzerland), and an enzyme solution, by means of a piston pump (model LKB 2249, Pharmacia, Sweden). The CSTR was equipped with a $\mathrm{pH}$ electrode (model HA 405 DXKS8, Ingold Meßtechnik, Switzerland). In conjunction with a titrator/controller (model 614, Metrohm, Switzerland) it served as a $\mathrm{pH}$ control by feeding a $4 \mathrm{~m} \mathrm{KOH}$ with an autoburette (model E535, Metrohm, Switzerland). The tubular reactor, fed by the outlet of the CSTR, consisted of a jacketed glass tube (Quickfit, Germany) with an internal diameter of $40 \mathrm{~mm}$ in sections with lengths of 33,66 , and $159 \mathrm{~cm}$, respectively. The sections could be assembled as required. Tubular reactors with effective volumes of 1.82 and 3.04 litres have been used. The tubular reactor was equipped with static mixers (model SMX 39, Sulzer SA, Switzerland) in order to obtain a reactor with low backmixing [7]. The temperature of the tubular reactor was controlled independently of that of the CSTR by means of a thermostat.

\section{Results and discussion}

The $\mathrm{pH}$ characteristics of the reaction system is of primary importance in a continuously operated reactor. Trypsin exhibits optimal proteolytic activity in the $\mathrm{pH}$ range 7-9 and activity decreases rapidly at $\mathrm{pH}$ values lower than 6. At alkaline $\mathrm{pH}$, however, trypsin is sensitive to accelerated deactivation by autodigestion. Protein hydrolysis in the $\mathrm{pH}$ range of optimum trypsin activity is accompanied by a considerable production of hydronium ions [5] and a reaction without $\mathrm{pH}$ control at an initial $\mathrm{pH}$ of 7-9 would suffer from a sharp drop in $\mathrm{pH}$. For this reason, a single tubular reactor with single passage would not be the optimum choice due to the inability to control $\mathrm{pH}$.

\section{Analysis of pH shift during protein hydrolysis}

The $\mathrm{pH}$ profile in reactors operated without $\mathrm{pH}$ control may be estimated roughly by applying a simple model. It is assumed that the substrate is devoid of buffering capacity at operating $\mathrm{pH}$, and that proteins are cleaved by liberating amino- and carboxyl groups, which both undergo dissociation leading to equilibria between their acid- and base forms. The balance of hydronium ions produced per fraction of peptide bonds cleaved and referred to the initial concentration of peptide bonds leads to [5]:

$$
x_{\mathrm{H}}=\frac{1}{c_{0}} \frac{\mathrm{d}\left[\mathrm{H}_{3} \mathrm{O}^{+}\right]}{\mathrm{d} X}=x_{\mathrm{N} . \mathrm{h}}-x_{\mathrm{C}, \mathrm{a}}
$$

with:

$$
x_{\mathrm{N}, \mathrm{b}}=\frac{1}{1+10^{\left(\mathrm{pK} \mathrm{K}_{\mathrm{a}, \mathrm{N}}-\mathrm{pH}\right)}} \text { and } x_{\mathrm{Ca}}=\frac{1}{1+10^{\left(\mathrm{pH}-\mathrm{pK}_{\mathrm{a}, \mathrm{C}}\right)}}
$$

since hydronium ions are only created by appearance of the deprotonated amino group (base form), and hydronium ions are consumed by generation of the protonated carboxyl group (acid form). The degree of hydrolysis $(X)$ should not be confused with the fraction of soluble protein $(Y)$. The same may be added for the initial concentration of peptide bonds $\left(c_{0}\right)$ and the initial protein concentration $\left(S_{0}\right)$. The buffering capacity of the reaction system is described by the buffering capacity of those dissociating groups liberated by proteolysis. Thus, the buffering capacity of the reaction system, neglecting the dissociation of water, may be written as [8]:

$$
\beta=-\frac{\mathrm{d}\left[\mathrm{H}_{3} \mathrm{O}^{+}\right]}{\mathrm{dpH}}=\ln (10)\left[c_{0} X\left(x_{\mathrm{N} . \mathrm{a}} x_{\mathrm{N}, \mathrm{b}}+x_{\mathrm{C}, \mathrm{a}} x_{\mathrm{C}, \mathrm{b}}\right)\right]
$$

Combining equations 1 and 2 leads to the following:

$$
\int_{\mathrm{pH}}^{\mathrm{pH}_{\mathrm{i}}} \mathrm{H}_{\mathrm{i}} \mathrm{dpH}=-c_{0} \int_{X_{\mathrm{t}}}^{X_{\mathrm{t}}} \frac{x_{\mathrm{H}}}{\beta} \mathrm{d} X
$$

from which the $\mathrm{pH}$ profile as a function of the fraction of peptide bonds cleaved may be obtained by numerical integration. If characteristic parameters for the actual reaction system are used [5], the $\mathrm{pH}$ profiles shown in Fig. 2 are obtained. The initial concentration of peptide bonds $\left(c_{0}\right)$ has been estimated to correspond approximately to the actual reaction conditions. According to the assumptions applied, extremely steep

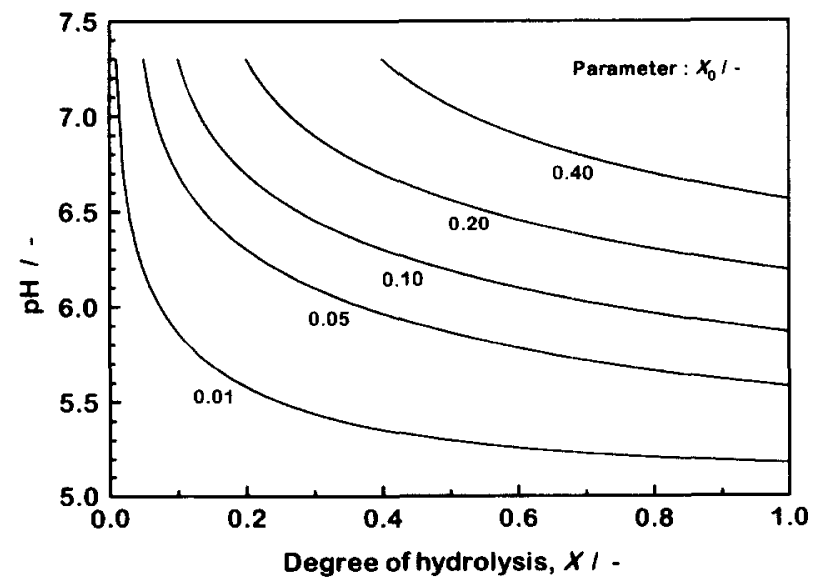

Fig. 2. Simulation of the $\mathrm{pH}$ shift due to protein hydrolysis at various initial degrees of hydrolysis. (Parameters: $\mathrm{pK}_{\mathrm{a}, \mathrm{N}}=7 \cdot 0 ; \mathrm{pK}_{\mathrm{a}, \mathrm{C}}=3 \cdot 1 ; \mathrm{c}_{0}=0.4 \mathrm{~mol} \mathrm{l}^{-1}$ ) 


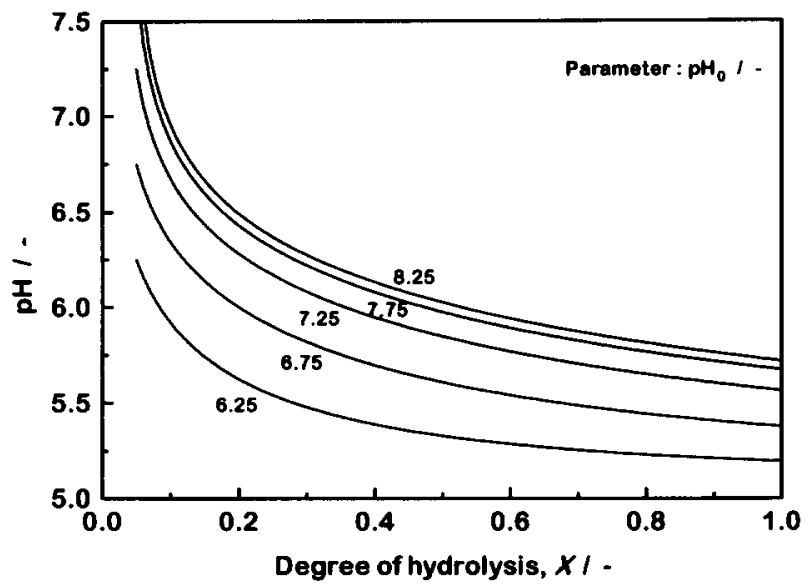

Fig. 3. Simulation of the $\mathrm{pH}$ shift due to protein hydrolysis at various initial $\mathrm{pH}$. (Parameters: $\mathrm{pK}_{\mathrm{a}, \mathrm{N}}=7 \cdot 0 ; \mathrm{pK}_{\mathrm{a}, \mathrm{C}}=3 \cdot 1$; $\left.c_{0}=0.4 \mathrm{~mol} \mathrm{l}^{-1}\right)$

$\mathrm{pH}$ profiles may be obtained in the absence of hydrolysis products. A pre-hydrolysis of $5 \%$ would still lead to a $\mathrm{pH}$ drop of the order of 1.5 . Higher degrees of pre-hydrolysis, however, would alleviate the problem of $\mathrm{pH}$ stabilisation more and more, because a small drop in $\mathrm{pH}$ would have a negligible effect on enzymic productivity. The simulation given in Fig. 3 shows that an initial $\mathrm{pH}$ higher than 8 would have no appreciable effect on stabilising the operating $\mathrm{pH}$.

\section{Batch reaction at floating $p H$}

The influence of operating at floating $\mathrm{pH}$ was assessed by studying the reaction system in a stirred batch reactor. These experiments were performed by starting the reaction under $\mathrm{pH}$ control and switching to floating-pH operation when a predetermined fraction of soluble protein (NPN) was attained. The reaction was followed by analysing NPN as a function of the operating time. Data for operation at $55^{\circ} \mathrm{C}$ are shown in Fig. 4, in which the results for operation at floating $\mathrm{pH}$ are compared with those obtained under $\mathrm{pH}$ control at $\mathrm{pH} 7 \cdot 3$ taken from a previous publication [9]. As expected, the performance of a batch reactor operated at constant $\mathrm{pH}$ was only approached, when floating-pH operation was switched on at high degrees of pre-hydrolysis. A similar series of experiments was performed at an operating temperature of $60^{\circ} \mathrm{C}$ (Fig. 5). Switching to floating $\mathrm{pH}$ affected the hydrolysis at lower operating times, but was beneficial at higher operating times, particularly, when the operating mode was switched at high degrees of conversion. Thus, operation at floating $\mathrm{pH}$ apparently reduced deactivation by autodigestion, if the drop of $\mathrm{pH}$ was moderate. Higher operating temperatures are always of considerable interest owing to lowered risk of microbial infection. The experimental $\mathrm{pH}$ profiles as a function of batch reactor operating time are shown in Fig. 6 for

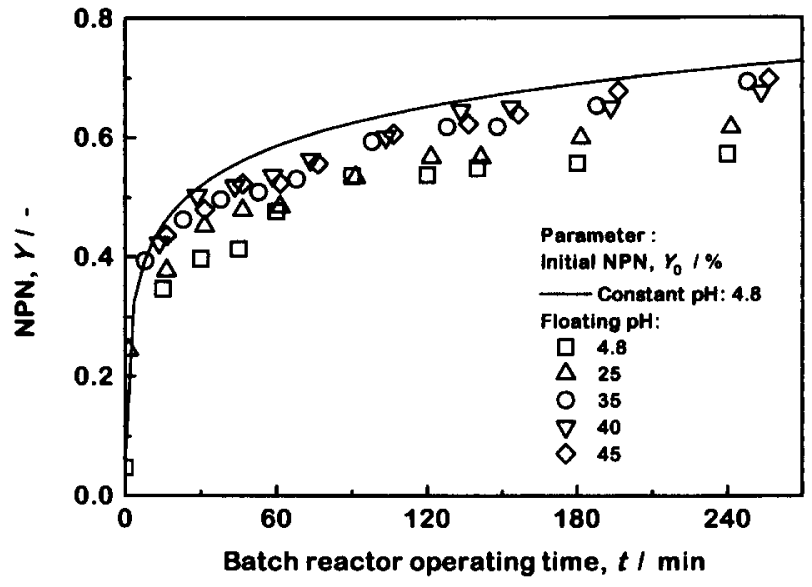

Fig. 4. Batch reactor performance at floating $\mathrm{pH}$ and varied initial fractions of soluble protein $\left(T_{\mathrm{c}}=55^{\circ} \mathrm{C} ; \mathrm{pH}_{0}=7 \cdot 3\right)$. The solid line shows the performance at a constant $\mathrm{pH}$ of 7.3 for comparison [9].

the series of experiments at $55^{\circ} \mathrm{C}$. These profiles compare well with the simulated profiles discussed before based on a rather simple model. When the $\mathrm{pH}$ drop at an operating time of $4 \mathrm{~h}$ in a batch reactor was taken as a characteristic quantity the correlations shown in Fig. 7 were observed. A pH drop of less then one unit may only be obtained in a tubular reactor or a batch reactor starting with an initial NPN in excess of $35 \%$.

\section{Performance of a CSTR}

This $\mathrm{pH}$ characteristic of the reaction system made it unattractive to operate a single tubular reactor in which $\mathrm{pH}$ control would not be possible. In contrast a continuous stirred tank reactor (CSTR) may be operated easily with $\mathrm{pH}$ control, but would show lower productivity due to backmixing. The kinetics of the

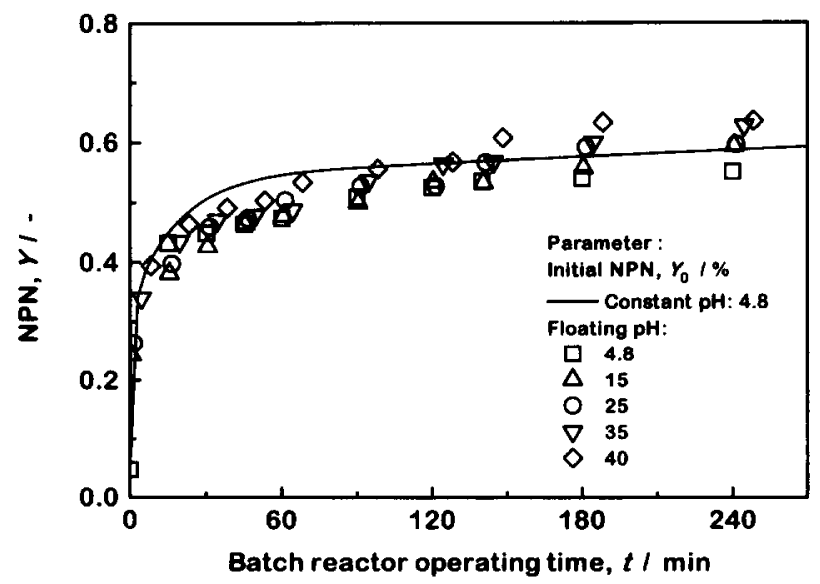

Fig. 5. Batch reactor performance at floating $\mathrm{pH}$ and various initial fractions of soluble protein $\left(T_{\mathrm{c}}=60^{\circ} \mathrm{C} ; \mathrm{pH}_{0}=7 \cdot 3\right)$. The solid line shows the performance at a constant $\mathrm{pH}$ of $7 \cdot 3$ for comparison [9]. 


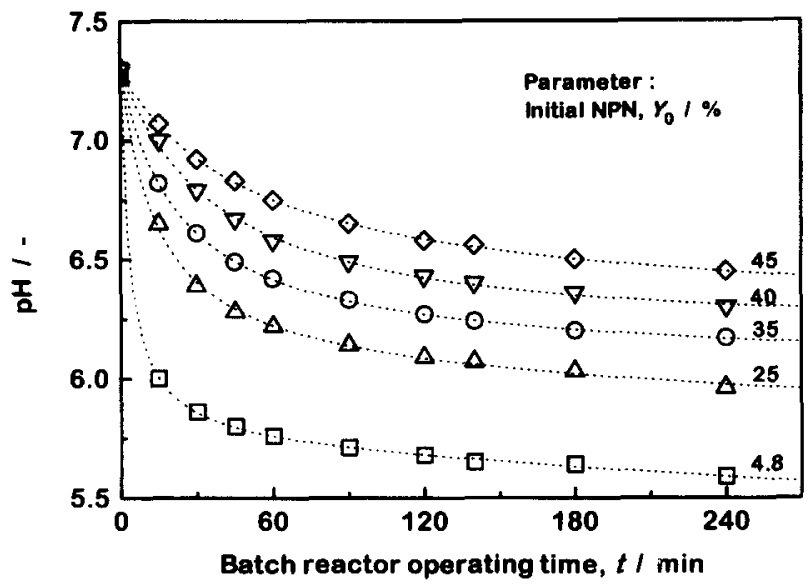

Fig. 6. Profile of $\mathrm{pH}$ in a batch reactor operating at varied initial fractions of soluble protein. $\left(T_{\mathrm{c}}=55^{\circ} \mathrm{C} ; \mathrm{pH}_{0}=7 \cdot 3\right)$.

reaction system, characterized by high initial rates, but severe product inhibition [9], suggested that reasonable productivities may still be obtained even in a CSTR operating at a moderate NPN and therefore a low residence time. In Fig. 8 NPN profiles as a function of residence time in a CSTR operated at different temperatures are given in comparison with profiles known from stirred-batch reactors [9]. As expected, the CSTR operation always led to considerably lower yields of soluble protein at the same operating times. The decline in NPN with increasing time observed for experiments at $70^{\circ} \mathrm{C}$ was due to a non-trivial deactivation mechanism in combination with the balance of a CSTR $[10,11]$. For practical reasons, an operating temperature of $55^{\circ} \mathrm{C}$ would be adequate for operating a CSTR at low residence times. The operation of a $\mathrm{CSTR}$ at $55^{\circ} \mathrm{C}$, but at a different operating $\mathrm{pH}$ gave the results shown in Fig. 9. As anticipated, a better performance was obtained when operating at a $\mathrm{pH}$ of 7.8 instead of lower values.

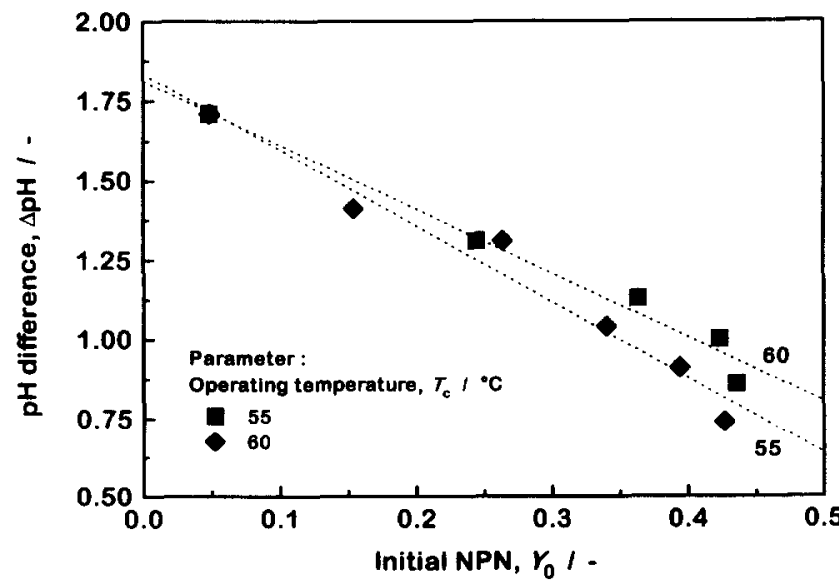

Fig. 7. Drop of $\mathrm{pH}$ for batch reactor operation at floating $\mathrm{pH}$.

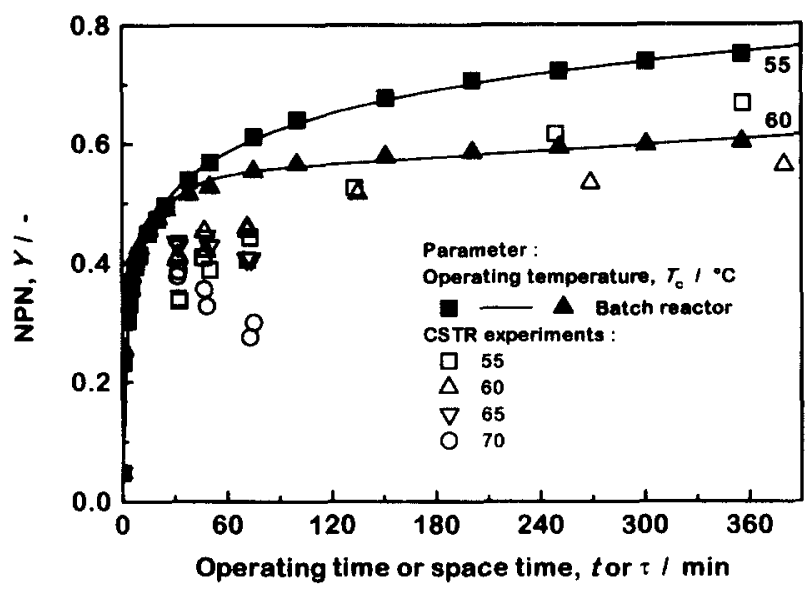

Fig. 8. Performance of a continuous stirred tank reactor (CSTR) operated at $\mathrm{pH} 7 \cdot 3$ at varied operating temperatures. The solid lines and symbols show the performance of batch reactors at a constant $\mathrm{pH}$ of $7 \cdot 3$ for comparison [9].

\section{Simulation of a staged reactor}

For continuous reactor operation, a $\mathrm{pH}$-controlled CSTR was used as a first stage and high yields of soluble protein were obtained by combining the CSTR with a tubular reactor (TR) operating at long residence times under floating $\mathrm{pH}$. Continuous reactor operation requires considerable amounts of substrate and enzyme. However, such a reactor combination may be simulated by operating a CSTR, taking the partially converted reaction mixture at the reactor exit and treating it once again for a given time at the desired operating temperature without $\mathrm{pH}$ control in a reactor with negligible backmixing. Thus, the tubular part of the reactor was simply simulated by means of a batch reactor. Experimental simulation for both operating temperatures, 55 and $60^{\circ} \mathrm{C}$ were performed and the results are shown in Fig. 10. For isothermal operation,

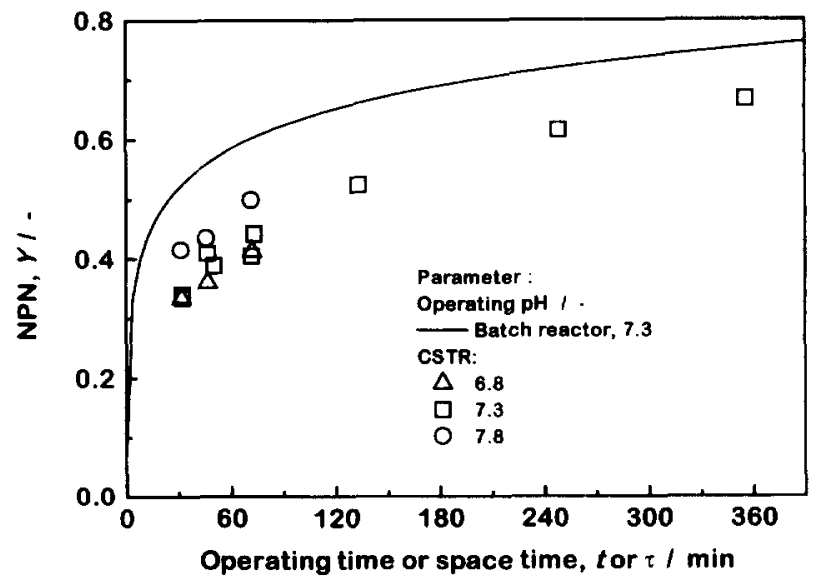

Fig. 9. Performance of a continuously operated stirred tank reactor (CSTR) operated at $55^{\circ} \mathrm{C}$ and varied $\mathrm{pH}$. The solid line shows the performance of a batch reactor at a constant $\mathrm{pH}$ of $7 \cdot 3$ for comparison [9]. 


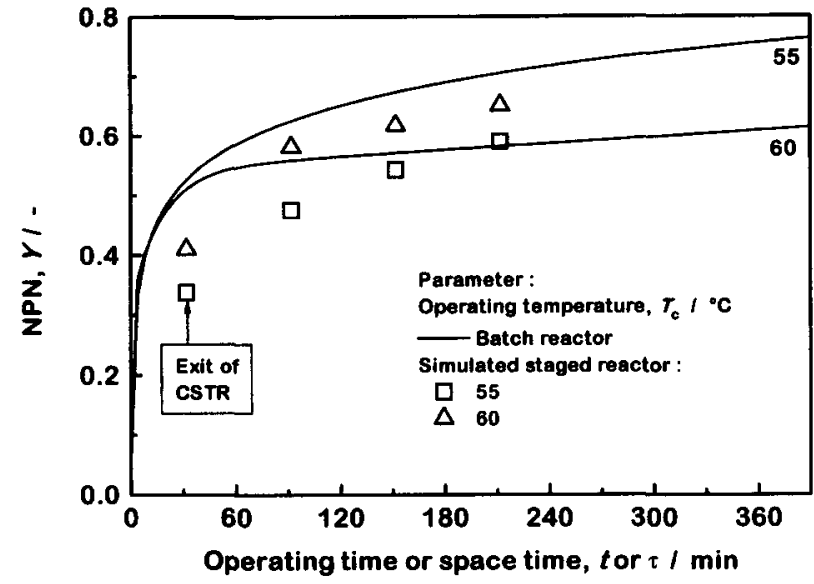

Fig. 10. Performance of an experimentally simulated staged reactor operated at 55 and $60^{\circ} \mathrm{C}$, with identical temperatures in both stages, stirred tank and simulated tubular device. The pH was kept at 7.3 in the CSTR. The solid lines show the performance of batch reactors at a constant $\mathrm{pH}$ of 7.3 for comparison [9].

an operating temperature of $60^{\circ} \mathrm{C}$ was preferred and, knowing the influence of the operating $\mathrm{pH}$ on the performance of the CSTR, a series of experiments was performed by changing both the operating temperature and the $\mathrm{pH}$ of the CSTR. The tubular reactor was simulated as discussed above by treating the reaction mixture in a batch reactor for a given time at $60^{\circ} \mathrm{C}$. The results are given in Fig. 11 and clearly show that maintaining the CSTR at $55^{\circ} \mathrm{C}$ and a $\mathrm{pH}$ of 7.8 was optimal for obtaining high yields of soluble protein for reasonable residence times in the simulated tubular device kept at $60^{\circ} \mathrm{C}$.

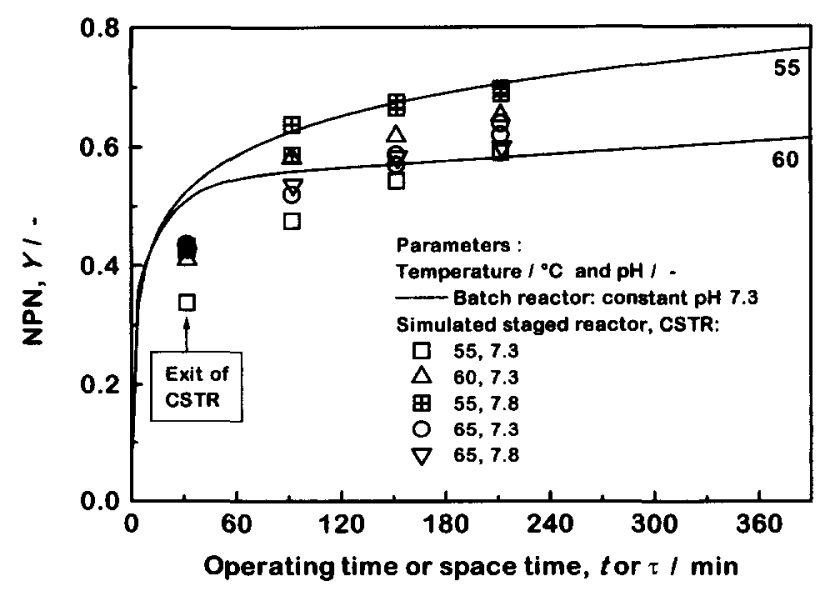

Fig. 11. Performance of an experimentally simulated staged reactor. The CSTR was kept at various temperatures and $\mathrm{pH}$ values, whilst the tubular reactor was simulated for an operating temperature of $60^{\circ} \mathrm{C}$. The solid lines show the performance of batch reactors at a constant $\mathrm{pH}$ of 7.3 for comparison [9].

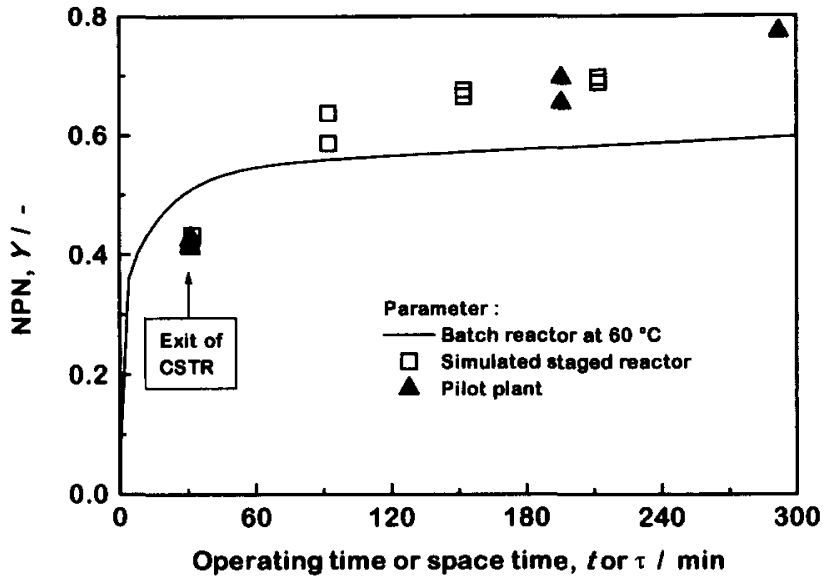

Fig. 12. Performance of the pilot-plant reactor, the stirred tank of which was operated at a constant $\mathrm{pH}$ of 7.8 and $55^{\circ} \mathrm{C}$, whilst the tubular device was kept at $60^{\circ} \mathrm{C}$. For comparison data are given for a simulated staged reactor operated under identical conditions and a batch reactor operated at a constant $\mathrm{pH}$ of $7 \cdot 3$ [9].

\section{Pilot-plant studies}

The pilot-plant consisting of a stirred tank and a tubular device (Fig. 1) was operated under the conditions outlined above. The CSTR was kept at a residence time of $30 \mathrm{~min}$ at $55^{\circ} \mathrm{C}$ and $\mathrm{pH} 7 \cdot 8$, whereas the residence time in the tubular part of the reactor was changed by altering the length of the tube. The results obtained from the pilot-plant are given in Fig. 12 together with the results of the simulated staged reactor under the same operating conditions. As expected from the use of static mixers as internals, the tubular reactor behaved like a plug-flow reactor.

\section{Conclusion}

Analysis of the limited hydrolysis of whey protein by soluble trypsin has led to the development of a continuously operated reactor comprising a stirred tank in series with a tubular device. The stirred tank allowed for the control of $\mathrm{pH}$ by titrating most of the hydronium ions produced by the reaction and maintaining the $\mathrm{pH}$ in the optimum range for trypsin activity. The tubular device equipped with static mixers behaved like an ideal tubular reactor and was operated at high residence times, in order to obtain a fraction of soluble protein, which was required to exceed $60 \%$. This has been achieved by combining these two reaction devices with opposite behaviour with respect to backmixing [12].

\section{References}

1. Jost, R., Monti, J. C. and Pahud, J. J., Whey protein allergenicity and its reduction by technological means. Food Technology, 1987, 41, 118-121. 
2. Monti, J. C. and Jost, R., Solubilization of cheese whey protein by trypsin and a process to recover the active enzyme from the digest. Biotechnology and Bioengineering, 1978, 20, 1173-1185.

3. Boudrant, J. and Cheftel, C., Continuous proteolysis with a stabilized protease. II. Continuous experiments. Biotechnology and Bioengineering, 1976, 18, 1735-1749.

4. Deeslie, W. D. and Cheryan, M., A CSTR-hollowfiber system for continuous hydrolysis of proteins. Factors affecting long-term stability of the reactor. Biotechnology and Bioengineering, 1982, 24, 69-82.

5. Margot, A., Flaschel, E. and Renken, A., Continuous monitoring of enzymatic whey protein hydrolysis. Correlation of base consumption with soluble nitrogen content. Process Biochemistry, 1994, 29, 257-262.

6. Chase, T. and Shaw, E., Titration of trypsin, plasmin and thrombin with p-nitrophenyl p'-guanidinobenzoate $\mathrm{HCl}$. Methods in Enzymology, 1970, 19, 20-27.

7. Flaschel, K., Nguyen, T., and Renken, A., Improvement of homogeneous tubular reactors operated at low Reynolds number. In Proceedings of the 5th European Conference on Mixing, BHRA, Bedford (UK), 1985, pp. 549-554.
8. Flaschel, E., Crelier, S., Schulz, K., Huneke, F.-U., and Renken, A., Process development for the optical resolution of phenylalanine by means of chymotrypsin in a liquid-liquid-solid three-phase reaction system, In Biocatalysis in Non-Conventional Media, ed. J. Tramper et al. Elsevier Science Publishers, Amsterdam, 1992, pp. 163-170 (Progress in Biotechnology, 1992, 8, 163-170).

9. Flaschel, E., Margot, A. and Renken, A., Empirical kinetic models for tryptic whey-protein hydrolysis. Process Biochemistry, 1997, 32, 217-223.

10. Margot, A., Richoz, C., Flaschel, E. and Renken, A., Einfluß der Trypsin-Desaktivierung auf die Hydrolyse von Molkeproteinen. Chemie-IngenieurTechnik, 1992, 64, 551-553.

11. Flaschel, E., Margot, A., Dohmen, M. and Renken, A., Conversion-space time profiles of stirred tank reactors continuously fed with reactants and catalyst under conditions of strong catalyst deactivation. Chemical Engineering Science, 1995, 50, 1143-1147.

12. Flaschel, E., Enzyme kinetics and reactor design. In Biocatalytic Production of Amino Acids and Derivatives, ed. J. D. Rozzell and F. Wagner, Hanser Publishers, New York, 1992, pp. 321-407. 